\title{
Position of the European Court on the Implementation of Decisions by National Courts in Latvia and in Finland which are in Legal Force
}

\author{
Vladimir Jilkine \\ Law Office Kari Korhonen, Helsinki, Finland \\ info@lawcenter.fi
}

\begin{abstract}
The article deals with the legal meaning and position of the European Convention and the decisions of the European Court of Human Rights on the implementation of decisions by national courts which are in legal force. Case-law of the Republic of Latvia Supreme Court and Supreme Court of the Republic of Finland shows that the European Convention refers to important legal instruments which must be taken into account when deciding on the case. Judicature of the Republic of Latvia Supreme Court shows that the European Convention refers to important legal instruments which must be taken into account when deciding on the case. When considering claims for cancellation of in force decisions on the basis of the ECHR Resolution on the recognition of a violation by Finland of articles of the Convention, the Court refers to numerous decisions of the European Court of affecting the interests of Finland and the other member states of the Convention, details examining and comparing the circumstances of each case. At the same time the final basis for a decision is based on the National Constitution of the Republic of Finland and Procedure.
\end{abstract}

Keywords: international law, European Convention of Human Rights, the supremacy of law and the supreme law of the Constitution. 
Vladimir Jilkine. Position of the European Court on the Implementation of Decisions by National Courts in Latvia and in Finland which are in Legal Force

\section{Introduction}

The aim of the article is to define the position of the European Court on the implementation of decisions by national courts in Latvia and in Finland which are in legal force and to determinate the most effective mechanisms to enforce the ECHR decisions in the national court proceedings.

The historical method has allowed to consider the most important stages of the development of control mechanism of the European Convention.

The comparative legal method was the basis for the study places of the European Convention in legal systems of the Council of Europe member states. The comparative method is used to analyse the opinions.

Empirical materials are developed by means of induction and deduction. Theoretical modelling is applied to illustrate the applicable legislation and support potential models of action in line with statutory requirements.

The dialectical method was used in analysing the implementation of the European Convention, while preserving the sovereignty of the Council of Europe member states.

The enforcement of the method of analysis and synthesis has secured a systemic approach to the study of the theory of statehood and law.

\section{Results}

The Judicature of the Supreme Court of Latvia shows that the Convention is deemed to be an important legal document. For example, one may refer to the Report to the Government of the Republic of Latvia on implementation of the ECHR judgements on the case of Deniss Čalovskis dated 2 October, 2015 DH-DD(2015)1016. On 1 October, 2015 the Parliament adopted amendments to the relevant parts of the Criminal Procedure Law.

The same conclusion was made by the author as based on the references in this Doctoral thesis, discussed and analysed earlier with respect to the common law precedents - to 171 resolutions passed by the Supreme Court of Finland in 2010-2015, 87 judgements of 2015 and 167 judgements of the Supreme Administrative Court of Finland in 2015.

\section{Discussion}

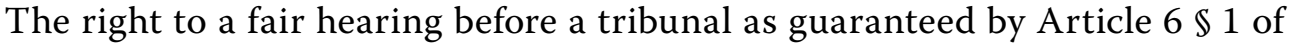
the Convention must be interpreted in the light of the Preamble to the Convention which declares, among other things, the rule of law to be part of the common heritage of the Contracting States. One of the fundamental aspects of the rule of law is the principle of legal certainty which requires, inter alia, where the courts have finally determined an issue, their ruling should not be called into question [5]. 
Vladimir Jilkine. Position of the European Court on the Implementation of Decisions by National Courts in Latvia and in Finland which are in Legal Force

The Court reiterates that Article $6 \$ 1$ secures everyone's right to have any claim relating to their civil rights and obligations brought before a court or tribunal. In this way it embodies the "right to a court", of which the right of access, i.e. the right to institute proceedings before courts in civil matters, constitutes one aspect. However, that right would be illusory if a Contracting State's domestic legal system allowed a final, binding judicial decision to remain inoperative to the detriment of one party. It would be inconceivable that Article $6 \$ 1$ should describe in detail procedural guarantees afforded to litigants - proceedings that are fair, public and expeditious - without protecting the implementation of judicial decisions; to construe Article 6 as being concerned exclusively with access to a court and the conduct of proceedings would be likely to lead to situations incompatible with the principle of the rule of law [7].

It should be noted that the ECHR in its judgements also pointed out that in some cases revision of judgements that have already entered into force was necessary. A departure from that principle of res judicata is justified only when made necessary by circumstances of a substantial and compelling character [11].

On the other hand, Protocol 15 to the European Convention states that the ECHR plays only a subsidiary role, while the states have a margin of appreciation and must in the first place protect the human rights in their jurisdiction. Nevertheless, it follows as well from Article 6 of the Convention that the right to fair judicial trial includes the right to timely enforcement of a court judgment.

In 2009 the ECHR made a number of important legal positions. It should be pointed out that one of the most significant features of the Convention system is that it includes a mechanism for reviewing compliance with the provisions of the Convention. Thus, the Convention does not only require the States Parties to observe the rights and obligations deriving from it, but also establishes a judicial body, the Court, which is empowered to find violations of the Convention in final judgments by which the States Parties have undertaken to abide (Article 19, in conjunction with Article $46 \mathbb{\$} 1$ ). In addition, it sets up a mechanism for supervising the execution of judgments, under the Committee of Ministers' responsibility (Article $46 \mathbb{\$} 2$ of the Convention). Such a mechanism demonstrates the importance of effective implementation of judgments. In any event, respondent States are required to provide the Committee of Ministers with detailed, up-to-date information on developments in the process of executing judgments that are binding on them (Rule 6 of the Committee of Ministers' Rules for the supervision of the execution of judgments and of the terms of friendly settlements - see paragraph 35 above). In this connection, the Court emphasises the obligation on States to perform treaties in good faith, as noted, in particular, in the third paragraph of the Preamble to, and in Article 26 of, the Vienna Convention on the Law of Treaties 1969 [12].

Since the appeal against conviction or punishment is a part of deliberation on a person's accusation of a criminal offence, the general plea for justice, as per Clause 1, Article 6 of the Convention, specified in respective provisions regarding the right to fair judicial trial, is applied as well to the hearing of appeal cases. The underlying principle 
is that the Convention is intended to guarantee not rights that are theoretical or illusory but rights that are practical and effective.

In addition, whilst Article $6 \mathbb{1}$ guarantees to litigants an effective right of access to the courts for the determination of their "civil rights and obligations", it leaves to the State a free choice of the means to be used towards this end [2].

The right to effective preparation of a case for review also supposes that a convicted person must be granted access to other documents, such as copies of minutes of court hearings, if this is necessary for effective exercise of his right to appeal. This also includes the duty of the state to preserve the evidence materials necessary for consideration of the appeal.

The practice of supervisory change of consummated court verdicts is realised in accordance with the international standard of legal certainty of judgment. The legal certainty requirement constitutes "one of the fundamental aspects of supremacy of law, represents its necessary consequence and a condition for realisation". In the case of Marckx vs. Belgium, the Court emphasised that the principle of legal certainty, which is necessarily inherent in the law of the Convention as in Community Law, dispenses the Belgian State from re-opening legal acts or situations that antedate the delivery of the present judgment. Moreover, a similar solution is found in certain Contracting States having a constitutional court; their public law limits the retroactive effect of those decisions of that court that annul legislation [8].

Nonetheless, as known, legal certainty implies inevitability of legal rules, on the one hand, and inadmissibility of revision of a consummated court sentence, on the other hand.

The author notes that the position of the European Court is not always expressed quite definitely and is sustainable.

Thus, in the Judgment (inter alia, X vs. Austria, No. 7761/77) the Court stated the right to appear does not feature among the rights and freedoms guaranteed by the Convention, including those recognised under Article 6. According to the constant case-law of the Commission, Article 6 of the Convention does not apply to proceeding for re-opening a trial given that someone who applies for his case to be re-opened and whose sentence has become final, is not someone "charged with a criminal offence" within the meaning of the said Article [13].

In 2004, the Court expressed a different position in the case of Nikitin $v s$. Russia. The mere possibility of reopening a criminal case is therefore prima facie compatible with the Convention, including the guarantees of Article 6. However, certain special circumstances of the case may reveal that the actual manner in which it was used impaired the very essence of a fair trial. In particular, the Court has to assess whether, in a given case, the power to launch and conduct a supervisory review was exercised by the authorities so as to strike, to the maximum extent possible, a fair balance between the interests of the individual and the need to ensure the effectiveness of the system of criminal justice. In this case the Court has found that the supervisory review was compatible with the non bis in idem principle enshrined in Article 4 of Protocol No. 7, 
Vladimir Jilkine. Position of the European Court on the Implementation of Decisions by National Courts in Latvia and in Finland which are in Legal Force

which itself is one aspect of a fair trial. The mere fact that the institution of supervisory review as applied in the present case was compatible with Article 4 of Protocol No. 7 is not, however, sufficient to establish compliance with Article 6 of the Convention [10].

The Court reiterated that, as it was previously found, initiating a supervisory procedure may raise legal certainty issues, for instance, the judgements on civil cases were a subject to supervisory review for an indefinite period, for relatively minor reasons. The situation with criminal cases is somewhat different, at least in respect of acquittals, because the demands of their revision may be claimed only for one year from the date the acquittal entered into force.

Moreover, the Court clarified that legal certainty demands are not absolute. In criminal cases, they can be viewed in conjunction, for instance, with Article $4 \mathbb{\$} 2$ of Protocol No. 7 which explicitly allows the state to reopen the proceedings in the light of new circumstances or when there is a material breach in previous processes which resulted in incorrect resolution of the case.

The author notes that the Court has consistently appealed to modern interpretation of the Convention from the point of view of the present-day conditions, for instance, in the case of Anthony Tyrer [4]. The Court also recalled that the Convention is a living instrument which, as the Commission rightly stressed, must be interpreted in the light of present-day conditions. In the case now before it the Court cannot but be influenced by the developments and commonly accepted standards in the penal policy of the member states of the Council of Europe in this field "mater semper certa est".

The Finnish Court of Appeal in Kouvola referred for the first time to Article 6, 3b of the Convention voicing the suspect's right to have sufficient time and adequate facilities for preparation of his defence in 1991 [15].

In considering a case in the Supreme Court, the Court recognised a procedural error in the judicial proceedings at the Court of Appeal, on the basis of Article 14 of the International Covenant on Civil and Political Rights and Article 6 of the Convention [14].

Article 14 [Subclause g] of the International Covenant on Civil and Political Rights provides for the individual's right "not to be compelled to testify against himself or to confess guilt" in any criminal charges. The Supreme Court recognised that the suspect had a right not to testify against himself and not to accept the charges, and the Court ordered payment of reasonable compensation for unlawful detention.

The district court of Helsinki in the case of Marttinen in 2000, considering the debtor's criminal case, sequestered the property.

Mikko Marttinen was suspected in 2000 of debtor's fraud, provision of non-reliable information about his assets and property, in debt recovery and bankruptcy procedures. His creditors, tax authorities and the bank served an application to the police requesting investigation of the crime. During the investigation, the suspect refused to provide testimony at the bailiffs' department office, arguing that his testimony would affect the preliminary investigation on suspicion of the debtor's fraud. On the same day, the bailiff issued a judgement ordering the applicant to provide this information under 
the threat of administrative fine in the amount of 33,638 EUR, as the applicant had received an order for recovery of debts in the amount of 9.7 million FIM. On the appointed day the applicant did not appear for interrogation and sent a message stating that he was not going to provide the sought information, referring to Article 6 of the Convention.

Helsinki Court of First Instance noted that the actions of the bailiffs department concerned not only the criminal case, but also the protection of creditors' rights and provision of remedies specified in chapter $3 \mathbb{3} 3 \mathrm{~g}$ of the Law on enforced recovery [1]. The court passed a decision according to which the convict did not have the right to refuse giving explanations to the bailiffs.

Helsinki Appeal Court referred to the case of Fayed $v s$. the United Kingdom, which established that the procedural jurisdiction ensures application of preliminary investigation of economic and commercial activity in regulation of public interest, i.e. it must reflect "fair balance" between the need to secure the public interest and the need to protect the basic human rights. For the same reasons, the Court of Appeal also recognised that enforcement of the bailiffs' rights referred to in Chapter $3 \$ 34 \mathrm{~g}$ of the Law on enforced recovery, subject to compliance with certain conditions relative to collection of necessary information for the authorities, can not be regarded as a valid reason for reviewing the lower court's judgement.

The Supreme Court of the Republic of Finland did not change the judgement of the Court of Appeal [16] and referred to the provisions of the national legislation (sections 33, 34 and 40 (2) of the Law on enforced recovery).

When considering the complaint of Marttinen $v s$. Finland [9], the ECHR cited the example of Shannon $v s$. the United Kingdom, cited above, $\mathbb{\$} 39-40$, where the debtor may refuse to provide such information in the course of criminal proceedings. The obligation to report the amount of income and capital for tax purposes, for instance, is a common rule for tax authorities of the Contracting states, and it would be difficult to imagine their efficient functioning, for instance, in terms of obtaining due information for tax purposes with reference to the case of Allan $v s$. the United Kingdom [3].

The European Court professed in the Judgement, $\mathbb{S} 60$, the precedent-setting right to remain mute and not to testify against oneself, which reflects the international standards underlying the concept of fair judicial trial. The right not to testify against oneself supposes, in particular, that the prosecution in a criminal case shall seek to prove its rightness in respect of the accused without resort to evidence obtained by coercion or pressure, contrary to the will of the accused. In this sense this right is closely connected with the principle of presumption of innocence contained in $\mathbb{2}$ of Article 6 of the Convention (see Saunders vs. the United Kingdom; Serves vs. France; Heaney and McGuinness vs. Ireland [3].

Accordingly, the ECHR considered that the "degree of compulsion" imposed on the applicant by enforcement of Article 34 of the Law on enforced recovery, aimed to force him to provide information to the bailiffs, would have destroyed the very essence of 
Vladimir Jilkine. Position of the European Court on the Implementation of Decisions by National Courts in Latvia and in Finland which are in Legal Force

his privilege not to testify against himself and the right to remain silent, with a reference to pre-trial investigation in the case of Shannon $v s$. the United Kingdom, $\mathbb{\$} 41$.

Accordingly, the ECHR considered that the "degree of compulsion" imposed on the applicant by enforcement of Article 34 of the Law on enforced recovery, aimed to force him to provide information to the bailiffs, would have destroyed the very essence of his privilege not to testify against himself and the right to remain silent, with a reference to pre-trial investigation in Finland reported to the ECHR that it would make changes in the legislation and the trial practice.

In the same year, on 20 October, 2009, the Supreme Court passed a judgement unprecedented in the history of Finland - quashed a criminal penalty inflicted upon Kari Uoti, referring to the above ECHR judgement in Marttinen case. The Supreme Court of Finland acknowledged that the suspect had no obligation to provide a report about his property to the bankruptcy manager, and that the suspect had a right not to disclose information that could be used against him.

Following the ECHR ruling in the Marttinen $v$ s. Finland case, and after revoking the Uoti sentence on the same basis, the Ministry of Justice of Finland set up a working group in January 2010 for developing a relevant bill and making amendments to the Bankruptcy Law, in particular as concerns the debtor's right to refuse testifying against himself. The Bankruptcy Law of Finland, as amended, entered into force from 1 January, 2013; the new article "Protection against self-incrimination" $\$ 5(31.1 .2013 / 86)$ entered into effect on 31 January, 2013: "If a debtor is a suspect in pre-trial investigation or an accused party of criminal charge, he is not obliged to provide the information to the bankruptcy administrator on the facts serving a ground for suspicion".

The adopted Bankruptcy Law precisely matches the Constitution of the Republic of Finland and the assumed obligations under the international human rights, in particular "The right to fair judicial trial" guaranteed by Article 6 of the Convention on Protection of Human Rights and Fundamental Freedoms, according to which every person, upon lodging of any criminal charges against him, has a right to fair and public trial within a reasonable time by an independent and impartial tribunal set up on the basis of law.

\section{Conclusions and evaluation}

The author specifically emphasises the consideration of the Auer case by the Court of Appeal when the previously imposed life sentence was cancelled in the course of examination of the case using references to the ECHR's legal precedent and the Constitution. The Supreme Court already cancelled the judgements of 19 October, 2012, the decisions of the District Court in 2010 and of the Court of Appeal in 2011; however, the County Court in December 2013 adjudged life sentence for a murder committed in 2006. The resolution of the Court of Appeal on cancellation of the previously imposed life sentence determinately came into effect after the Supreme Court denied permission for a new trial on 19 December, 2015. 
Vladimir Jilkine. Position of the European Court on the Implementation of Decisions by National Courts in Latvia and in Finland which are in Legal Force

The Supreme Court of Finland twice returned the case of Jiippi Oy to the Court of Appeal that acquitted all of the 14 previously convicted persons 10 years later.

As a result of the application of the European Convention and the law-cases of the ECHR in the Supreme Court of the Republic of Finland, the author refers to the case of Auer, when a life sentence judgment was cancelled.

Also, in the example of the considered decision of the three departments of the Supreme Court of the Republic of Latvia the author concludes that the practice of application of the European Convention use is increasing.

Demonstrative examples are the cases "V.S. vs. Latvia" and "Slivenko vs. Latvia", considered by the Supreme Court of Latvia.

\section{Eiropas Cilvēktiesību tiesas nostāja jautājumā par spēkā stājušos nacionālo tiesu nolēmumu izpildi Latvijā un Somijā}

\section{Kopsavilkums}

Rakstā tiek analizēta Eiropas Konvencijas juridiskā nozīme un Eiropas Cilvēktiesību tiesas nostāja jautājumā par spēkā stājušos nacionālo tiesu nolēmumu izpildi Latvijā un Somijā. Latvijas Augstākās tiesas un Somijas Republikas Augstākās tiesas judikatūra liecina, ka Eiropas Konvencija uzskatāma par svarīgu juridisku instrumentu, kas jāṇem vērā, izskatot lietu. Kad tiek izskatītas sūdzỉbas par spēkā esoša nolēmuma atcelšanu, pamatojoties uz ECT rezolūciju par pārkāpuma Somijā atzīšanu, tiesa atsaucas uz daudziem ECT lēmumiem par konvencijas pārkāpumiem Somijā un citās valstīs, detalizēti izskatot un salīdzinot apstākḷus katrā lietā. Vienlaikus galīgais lēmums ir balstìts uz Somijas Republikas Konstitūciju un procedūru.

Atslēgvārdi: starptautiskās tiesības, Eiropas Cilvēktiesību konvencija, likuma virsvadiba.

\section{References}

Description of legislative acts

1. The Code of Enforcement of Finland. Oikeudenkäymiskaari. 1.1.1734/4.

Description of court rulings

2. Case of Airey vs. Ireland, No 6289/73, 9 October, 1979. $\mathbb{2} 24$. The Convention is intended to guarantee not rights that are theoretical or illusory but rights that are practical and effective.

3. Case of Allan vs. the United Kingdom. No. 45839/99. 5 November, 2002. Available at: http:// hudoc.echr.coe.int/eng?i=001-60713\#\{“itemid”:[“001-60713”]\} 
Vladimir Jilkine. Position of the European Court on the Implementation of Decisions by National Courts in Latvia and in Finland which are in Legal Force

4. Case of Anthony Tyrer vs. the United Kingdom. No. 5856/72. 28 April, 1978. The Court must also recall that the Convention is a living instrument which, as the Commission rightly stressed, must be interpreted in the light of present-day conditions.

5. Case of Brumărescu vs. Romania, No. 28342/95. 28 October, 1999.

6. Case of Heaney and McGuinness vs. Ireland, No. 34720/97. 21 December, 2000.

7. Case of Hornsby vs. Greece, Golder vs. the United Kingdom, Philis vs. Greece, Bodrov vs. Russia.

8. Case of Marckx vs. Belgium, No. 6833/74. 13 June, 1979.

9. Case of Marttinen vs. Finland. Application No. 19235/03. Date of Judgment 21 July, 2009.

10. Case of Nikitin vs. Russia. No. 50178/99. 20 July, 2004. \$ 54, 57. Available at: http://hudoc. echr.coe.int/eng\#\{“fulltext": ["nikitin”]," documentcollectionid2":["GRANDCHAMBER","C HAMBER"],"itemid":[“001-61928”]\}

11. Case of Ryabykh vs. Russia, No. 52854/99, 24 July, 2003.

12. Case of Verein Gegen Tierfabriken Schweiz (VGT) vs. Switzerland, No. 3272/02, 30 June, 2009. Available at: http://hudoc.echr.coe.int/eng\#\{"fulltext": "Verein\%20Gegen\%20Tierfab riken"]," documentcollectionid2":["GRA

13. Case of X. vs. Austria. No 7761/77. 8 May, 1978.

Description of Finnish court rulings

14. KKO:1993:19, Judgment on 12.2.1993.

15. Kouvola Court of Appeal on 7.3.1991.

16. The decision of Helsinki Court of Appeal. HelHO:2007:22. 9.3.2007. Dnro: R 06/2199. 